\title{
ARAŞTIRMA / RESEARCH \\ Prevalence of lower urinary tract symptoms and influencing factors in women
}

Kadınlarda alt üriner sistem semptomlarının prevalansı ve etkileyen faktörler

Arife Zuhal Değirmencioğlu' (D), Semra Kocaöz ${ }^{\text {(D), Rabiye Çırpan }}{ }^{3}$ (D)

${ }^{1}$ Niğde Ömer Halisdemir University, Medical Faculty, Department of Internal Medicine, Niğde, Turkey.

2Niğde Ömer Halisdemir University, Niğde Zübeyde Hanım School of Health, Nursing Department, Department of Obstetrics and Gynecology, ${ }^{3}$ Department of Internal Medicine Nursing, Niğde, Turkey.

\begin{abstract}
Purpose: This study was conducted to determine the prevalence of LUTS in women and the influencing risk factors.

Materials and Methods: This cross-sectional study was conducted with 377 women who presented to the internal medicine outpatient departments of a training and research hospital for examination. The data were collected with a questionnaire form and the "Bristol Female Lower Urinary Tract Symptoms-Short Form (BFLUTS-SF)".

Results: The prevalence of at least one LUTS in women was $92.3 \%$. A statistically significant relationship was found between the menopausal status, chronic cough, stress urinary incontinence (SUI) presence in the mother or sister, the presence of a large baby and SUI in a previous pregnancy, and the BFLUTS-SF total scores.

Conclusion: We found that storage-related symptoms were most common in these women, and LUTS affected the sexual life and quality of life negatively. Therefore, it is necessary to increase the sensitivity of health professionals to this issue, and to raise the awareness of women about the risk factors, prevention, diagnosis and treatment of LUTS with future training.

Keywords: Lower urinary tract symptoms, prevalence,
\end{abstract} risk factors, women

\section{INTRODUCTION}

Lower urinary tract symptoms (LUTS), which are perceived as a subjective indicator of change in a disease or health condition ${ }^{1}$, can appear with a wide range of symptoms ${ }^{2}$. LUTS mainly consist of storage,
Öz

Amaç: $\mathrm{Bu}$ araştırma, kadınlarda alt üriner sistem semptomları (LUTS)'nın prevalansını ve bunu etkileyen risk faktörlerin belirlenmesi amacıyla yapılmıştır.

Gereç ve Yöntem: Kesitsel tipte olan bu çalışma, bir eğitim ve araştırma hastanesinin dahiliye polikliniklerine muayene olmak amacıyla gelen 377 kadınla yapılmıştır. Veriler, bir anket formu ve "Bristol Kadin Alt Üriner Sistem Semptomları-Kısa Form (BKAÜSS-KF)" ile toplanmiştır.

Bulgular: Kadınlarda en az bir LUTS'un görülme prevalansı \%92.3'dir. Menopozal durum, kronik öksürük, anne veya kız kardeşte stres üriner inkontinans (SUI) olma durumu, iri bebek doğumu ve önceki gebeliğinde SUI varlığ1 ile BKAÜSS-KF toplam puanları arasında istatistiksel olarak anlamlı bir ilişki olduğu saptanmıştır .

Sonuç: Kadinlarda en fazla depolamayla ilgili semptomların görüldüğü, LUTS'un seksüel hayatı ve yaşam kalitesini olumsuz yönde etkilediği tespit edilmiştir. $\mathrm{Bu}$ nedenle yapilacak olan eğitimlerle sağlık profesyonellerinin bu konudaki duyarlılıklarının artırılması ve kadınların LUTS'un risk faktörleri, önlenmesi, tanı ve tedavisi hakkında bilinçlendirilmesi gerekmektedir.

Anahtar kelimeler: Alt üriner sistem semptomlar1, prevalans, risk faktörleri, kadın

voiding and post micturition symptoms. In addition, LUTS also include symptoms related to pelvic organ prolapse and sexual intercourse, genital and lower urinary tract pain, genito-urinary pain, and syndromes related to lower urinary tract dysfunction ${ }^{1}$. LUTS affects the quality of life of women negatively and is a common health problem $^{3}$. Although the data 
collection tools, study population, and location vary, the prevalence of at least one LUTS in women has been reported to range between $18.7 \%$ and $84.0 \%$ in various studies ${ }^{4-17}$. The LUTS prevalence increases with increasing age in the female $e^{3,4,18}$.

Apart from age, the best-known risk factor ${ }^{19}$, multifactorial reasons are thought to play a role in LUTS development in women ${ }^{3}$. The risk factors may include race, obesity, depression, pregnancy, birth, menopause, hysterectomy, chronic cough, family history and employment ${ }^{2,3}$. In addition, pathological conditions affecting the bladder and urethra, pelvic organ prolapse, myomas, neurological diseases, surgeries conducted for urinary incontinence (UI), the drugs used, and many other risk factors can affect LUTS development in females ${ }^{18}$.

The worsening of the prevalence and severity of LUTS in women can have profound effects on the quality of life ${ }^{20}$. LUTS in women can cause financial and medical problems, emotional stress and sexual dysfunction, interruption of daily living activities, and restriction of social and physical activities ${ }^{3}$. In addition, LUTS can cause women to lose their jobs, decrease their work productivity, increase their special needs at home such as changing underwear, and result in depression, decreased self-confidence, and guilt ${ }^{2}$. Although LUTS leads to several health problems, the treatment-seeking behavior of women in this regard remain insufficient ${ }^{2,3}$. Therefore, health professionals should decrease the stigma towards the causes of bladder dysfunction in women and increase their awareness that LUTS can be treated.

Many studies have been conducted at the international level on the prevalence of LUTS in women and the influencing risk factors ${ }^{4-10,12-17}$. Although a limited number of studies conducted in different age groups and populations and using various measurement tools are present, we only found two studies where the prevalence of LUTS in women over the age of 18 years in Turkey was evaluated and these studies had not assessed the relevant risk factors ${ }^{11,12}$. There are many epidemiological studies explaining the risk factors thought to influence the development of LUTS in the literature, but there are still issues to be answered in this regard ${ }^{21}$. Therefore, this study was aimed to determine the prevalence of LUTS in women and the influencing risk factors.

\section{MATERIALS AND METHODS}

\section{Sample}

The population of this cross-sectional study consisted of all women aged 18 years or more who presented to the internal medicine outpatient department of a training and research hospital between 07 May and 06 August 2018. The hospital where the study is the only public hospital used together with the Niğde Ömer Halisdemir University Medical Faculty in the city. The training and research hospital is located in the city centre. At the hospital, there are 95 outpatient clinic room and 530 bed capacity. Since we could not determine how many women aged 18 years or more presented to the internal medicine outpatient departments to be examined using the registry system of the hospital where the study was conducted, the sample size formula with an unknown population was used to select the sample of this study ${ }^{22}$. The $\mathrm{p}$ value for this study was determined according to the study of Wang et $\mathrm{al}^{14}$. According to the $n=\mathrm{t}^{2} \cdot \mathrm{pq} / \mathrm{d}^{2}$ formula, and using a $95 \%$ confidence interval, and values of $\mathrm{t}=1.96, \mathrm{p}=0.61^{14}$, and $\mathrm{q}=0.39$, the minimum number of women that needed to be included in the study sample was found to be approximately 336 .

All women aged 18 or more who were married, able to understand and answer the questions, and who voluntarily agreed to participate in the study were included in the study. We did not use any exclusion criterion in this study and women who did not meet the inclusion criteria were not included. The internal medicine outpatient department was visited by 9876 women aged 18 or more who were married during the study period. Of the women visiting, $96.2 \%$ did not meet the inclusion criteria. This study was completed with 377 women who met the inclusion criteria.

\section{Measures}

A questionnaire created by the researchers after searching the literature for LUTS-related studies ${ }^{2-}$ 4,6,9,18,23, and the Bristol Female Lower Urinary Tract Symptoms-Short Form (BFLUTS-SF) were used to collect the study data.

\section{Clinical questionnaire}

The questionnaire included a total of 38 questions regarding the woman's socio-demographic information, pregnancy, birth, menopause and 
urogynecological history, personal habits, chronic diseases, and treatment-seeking behavior related to LUTS. The types of UI in women have been defined according to the definitions used in the Abrams et $\mathrm{al}^{1}$. study and the BLFUTS-SF questions. Women who stated not having menstruated for at least one year were considered to be menopausal.

\section{Bristol Female Lower Urinary Tract Symptoms- Short Form (BFLUTS-SF)}

BFLUTS-SF was developed by Jackson, Donovan and Brookes in 1996. Urinary incontinence symptoms, other LUTS symptoms, and their effects on sexual function and the quality of life are evaluated with this form consisting of 19 questions. The BFLUTS-SF consists of five sub-dimensions: storage, urination, incontinence, sexual function, and quality of life. This form does not have a cut-off value for determining the clinical presence of LUTS. An increase in BFLUTS-SF scores indicates that the severity and perceived importance of the symptoms has increased. The Cronbach alpha value of the original scale, which was reported to be valid and reliable, was $0.78^{24}$. The Turkish adaptation of the BFLUTS-SF was undertaken by Güngör and Yalçın in 2005 and the Cronbach alpha value was found to be 0.70 in their study ${ }^{25}$. The Cronbach alpha value of BFLUTS-SF was found to be 0.84 in the current study.

\section{Procedure}

The study was started after ethics committee approval from Niğde Ömer Halisdemir University Ethics Committee (Decision no: 2018/08-11) and written permission from the Niğde Province Directorate of Health and the hospital where the study was conducted were obtained. After the necessary institutional permissions were secured and before the questionnaire and BFLUTS-SF were administered, the researchers and an interviewer trained on the subject explained the purpose of the study to the subjects, asked them to voluntarily participate in the study, and obtained verbal permission and signed informed consent. Convenience sampling was used in the study. The data were completed with the face-to-face interview method and the procedure took 15-20 minutes on average.

\section{Statistical analysis}

The SPSS (24.0, IBM Corp., Armonk, NY) software program was used for the statistical analysis of the data. The reliability of the general total and subdimensions of BFLUTS-SF were evaluated with the Cronbach Alpha Coefficient. The Shapiro-Wilk test was used to determine whether the data were normally distributed for two-way comparisons. Descriptive statistics, Mann-Whitney U and KruskalWallis tests, multiple linear regression analysis were used for data analysis. Number, percentage, mean, standard deviation, median, $25 \%$ and $75 \%$ percentile values were used in the evaluation of the descriptive statistics of the study. The reliability of the general total and sub-dimensions of BFLUTS-SF were evaluated with the Cronbach Alpha Coefficient. Mann-Whitney U and Kruskal-Wallis tests were used for the comparison of independent variables and the total BFLUTS-SF scores. The relationship between risk factors, for which the statistical difference was significant after paired comparison, and the total BFLUTS-SF scores was investigated by multiple linear regression analysis (Enter model was used). The significance of the statistical results was evaluated at the $p<0.05$ level.

\section{RESULTS}

The mean age and body mass index (BMI) of the women in our study was $39.99 \pm 10.68$ years and $27.37 \pm 5.23 \mathrm{~kg} / \mathrm{m} 2$, respectively, and $33.4 \%$ were in the 30-39 years age group, $32.1 \%$ were primary school graduates, $36.3 \%$ were university graduate, $41.1 \%$ were working in paid employment, and $92.6 \%$ had social security. The ratio of women with three or more pregnancies, childbirths or miscarriages was $46.2 \%, 35.7 \%$ and $17.2 \%$, respectively.

The ratio of women with three or more pregnancies, childbirths or miscarriages was $46.2 \%, 35.7 \%$ and $17.2 \%$, respectively. It was found that $62.4 \%$ of the study subjects had only given birth vaginally, the labor had taken longer than 24 hours in $13.2 \%$, half had undergone episiotomy during the delivery, and $11.9 \%$ had given birth to a large baby. The rate of experiencing symptoms of stress urinary incontinence (SUI) during a previous pregnancy was $23.8 \%$ while $23.2 \%$ had experienced such symptoms after their previous childbirths. The rate of smokers was $19.4 \%, 9.3 \%$ had a chronic cough and $36.3 \%$ had constipation, and $11.1 \%$ stated they had diabetes (DM). Besides, $61.5 \%$ of the women had a history of urinary tract infection (UTI), and the mother or sister of $41.9 \%$ had experienced SUI symptoms. 
Table 1 presents the frequency of LUTS in women. We found that $92.3 \%$ of the women aged 18 years or more had experienced at least one symptom related to urinary storage, micturition or incontinence.

The rate of women experiencing storage-related symptoms was $88.6 \%$ and the prevalence of urgency, bladder pain, frequency, and nocturia was reported to be $76.9 \%, 50.7 \%, 50.4 \%$ and $32.7 \%$, respectively. LUTS related to micturition were reported by $47.5 \%$ of the women. The individual rate was $36.3 \%$ for intermittent stream, $25.2 \%$ for hesitancy and $18.0 \%$ for straining. UI symptoms were present in $52.3 \%$ of the women included in the study. The prevalence of UI, urge urinary incontinence (UUI), SUI, unpredictable incontinence and nocturnal incontinence was $39.8 \%, 37.9 \%, 37.4 \%, 15.4 \%$ and $6.6 \%$, respectively. The sexual life had been affected due to urinary symptoms in $13.8 \%$ of the women included in the study and $5.6 \%$ stated that they had urinary incontinence during sexual intercourse. Quality of life-related symptoms due to LUTS were present in $53.8 \%$ of the women. In this context, the daily activities had been affected in $35.0 \%$, the woman's life was affected in $30.2 \%$, the fluid intake was decreased in $32.4 \%$, the subject avoided going to places where they did not know the location of the restroom in $21.5 \%$, and the subject had to change her clothes during the day in $15.1 \%$ (Table 1). The percentage of women who had presented to a physician for the treatment of LUTS was $41.4 \%$ in this study.

The statistical relationship between the BFLUTS-SF total mean scores and medians and the age group, parity, mode of delivery, state of menopause, chronic cough and constipation symptom, presence of SUI in the mother or sister, BMI, DM, history of SUI in a previous pregnancy and postpartum period, giving birth to a large baby, and history of UTI was found to be significant in the paired comparisons performed $(p<0.05)$. The statistical relationship between the BFLUTS-SF total mean scores and medians and the other variables investigated was not found to be significant $(p>0.05)$ (Table 2).

Table 1. Lower urinary tract symptom frequency among Turkish women

\begin{tabular}{|c|c|c|}
\hline Variables & $n$ & $\%$ \\
\hline A minimum of one LUTS related to storage, voiding, or urinary incontinence & 348 & 92.3 \\
\hline Storage-related & 334 & 88.6 \\
\hline Urgency & 290 & 76.9 \\
\hline Bladder pain & 191 & 50.7 \\
\hline Frequency $(\leq 3 \mathrm{hr})$ & 190 & 50.4 \\
\hline Nocturia (more than once) & 123 & 32.7 \\
\hline Voiding-related & 179 & 47.5 \\
\hline Intermittent stream & 137 & 36.3 \\
\hline Hesitancy & 95 & 25.2 \\
\hline Straining & 68 & 18.0 \\
\hline Urinary incontinence-related & 197 & 52.3 \\
\hline Urinary incontinence & 150 & 39.8 \\
\hline Urge urinary incontinence & 143 & 37.9 \\
\hline Stress urinary incontinence & 141 & 37.4 \\
\hline Unpredictable incontinence & 58 & 15.4 \\
\hline Nocturnal incontinence & 25 & 6.6 \\
\hline Sexual function-related & 65 & 17.2 \\
\hline Negative influence on sex life & 52 & 13.8 \\
\hline Sexual activity-related leakage & 21 & 5.6 \\
\hline Quality of life-related & 203 & 53.8 \\
\hline Affects daily tasks & 132 & 35.0 \\
\hline Decreased fluid intake & 122 & 32.4 \\
\hline Negative overall effect on subject's life & 114 & 30.2 \\
\hline Avoid places without toilets & 81 & 21.5 \\
\hline Has to change outer clothing & 57 & 15.1 \\
\hline
\end{tabular}


According to the multiple regression model established with the significant potential variables, it was determined that the age group, parity, mode of delivery, constipation symptom, BMI, DM, history of SUI after previous childbirth, and history of UTI did not have a statistically significant effect on the BFLUTS-SF total scores $(p>0.05)$. The variables of the menopausal status, chronic cough symptom, presence of SUI in the mother or sister, the birth of a big baby, and a history of SUI in previous pregnancies were found to have a statistically significant effect on the BFLUTS-SF total scores $(p<0.05)$. Accordingly, the BFLUTS-SF total scores were found to be significantly higher (by 4.351 points) in menopausal women compared to those who were not menopausal $(p=0.025)$.)

Table 2. The distribution of the Bristol Female Lower Urinary Tract Symptoms-Short Form scores of women interviewed according to some characteristics

\begin{tabular}{|c|c|c|c|c|c|c|}
\hline \multirow[t]{2}{*}{ Characteristics } & \multirow[t]{2}{*}{$n$} & \multicolumn{3}{|c|}{ BFLUTS-SF Total Scores } & \multirow[b]{2}{*}{ Test } & \multirow[b]{2}{*}{$p$} \\
\hline & & $\bar{X} \pm S D$ & Median & 25 th- $75^{\text {th }}$ & & \\
\hline \multicolumn{7}{|c|}{ Age (years), mean $\pm \mathrm{SD}=39.99 \pm 10.68$} \\
\hline \multicolumn{7}{|l|}{ Age Group* } \\
\hline $19-29$ years & 70 & $7.54 \pm 5.86$ & 6.00 & $3.00-10.00$ & \multirow[t]{4}{*}{$X^{2}=19.018$} & \multirow[t]{4}{*}{$<0.0001$} \\
\hline $30-39$ years & 126 & $9.55 \pm 7.64$ & 8.00 & $4.00-13.00$ & & \\
\hline $40-49$ years & 111 & $10.23 \pm 7.99$ & 9.00 & $4.00-14.00$ & & \\
\hline$\geq 50$ years & 70 & $13.99 \pm 9.83$ & 11.50 & $6.00-20.00$ & & \\
\hline \multicolumn{7}{|l|}{ Parity* } \\
\hline 0 & 23 & $6.26 \pm 4.48$ & 4.00 & $3.00-10.00$ & \multirow[t]{4}{*}{$X^{2}=16.693$} & \multirow[t]{4}{*}{0.001} \\
\hline 1 & 62 & $8.97 \pm 7.77$ & 6.50 & $3.00-12.00$ & & \\
\hline 2 & 140 & $9.99 \pm 7.64$ & 8.00 & $4.00-13.00$ & & \\
\hline$\geq 3$ & 125 & $10.92 \pm 9.15$ & 11.00 & $6.00-17.00$ & & \\
\hline \multicolumn{7}{|c|}{ Spontaneous miscarriage** } \\
\hline Yes & 65 & $9.81 \pm 7.84$ & 8.00 & $4.00-15.00$ & $z=-0.447$ & 0.655 \\
\hline No & 312 & $10.28 \pm 8.21$ & 8.00 & $4.00-14.00$ & & \\
\hline \multicolumn{7}{|c|}{ Mode of delivery, ${ }^{a, *}$} \\
\hline Vaginal birth & 204 & $11.85 \pm 8.84$ & 10.00 & $6.00-17.00$ & $z=-2.981$ & 0.003 \\
\hline Cesarean section & 89 & $8.80 \pm 7.43$ & 7.00 & $4.00-12.00$ & & \\
\hline \multicolumn{7}{|c|}{ Labor taking longer than 24 hours $^{\mathrm{b}, * *}$} \\
\hline Yes & 43 & $10.98 \pm 7.24$ & 10.00 & $6.00-16.00$ & $z=-0.759$ & 0.448 \\
\hline No & 276 & $10.64 \pm 8.58$ & 9.00 & $4.00-15.00$ & & \\
\hline \multicolumn{7}{|c|}{ History of a previous big baby, } \\
\hline Yes & 39 & $14.44 \pm 11.26$ & 11.00 & $6.00-19.50$ & $z=-2.138$ & 0.032 \\
\hline No & 284 & $10.21 \pm 7.81$ & 8.50 & $4.00-14.00$ & & \\
\hline \multicolumn{7}{|c|}{ SUI in previous pregnancy b,** } \\
\hline Yes & 78 & $16.37 \pm 9.67$ & 16.00 & $8.00-24.00$ & $z=-6.515$ & $<0.0001$ \\
\hline No & 235 & $8.74 \pm 6.98$ & 7.00 & $4.00-12.00$ & & \\
\hline \multicolumn{7}{|c|}{ SUI in previous postpartum period ${ }^{b, * *}$} \\
\hline Yes & 76 & $16.88 \pm 8.86$ & 18.00 & $9.50-23.50$ & $z=-7.254$ & $<0.0001$ \\
\hline No & 238 & $8.64 \pm 6.96$ & 7.00 & $4.00-12.00$ & & \\
\hline \multicolumn{7}{|c|}{ Menopausal Status** } \\
\hline Yes & 71 & $14.15 \pm 10.30$ & 12.00 & $7.00-20.00$ & $z=-3.783$ & $<0.0001$ \\
\hline No & 306 & $9.28 \pm 7.27$ & 8.00 & $4.00-13.00$ & & \\
\hline \multicolumn{7}{|l|}{ Smoking* } \\
\hline Never smoked & 272 & $9.70 \pm 7.91$ & 8.00 & $4.00-14.00$ & $X^{2}=4.585$ & 0.101 \\
\hline Smoking & 73 & $11.62 \pm 8.35$ & 11.00 & $5.00-17.00$ & & \\
\hline Quit smoking & 32 & $11.25 \pm 9.33$ & 11.50 & $4.00-15.50$ & & \\
\hline \multicolumn{7}{|l|}{ Chronic cough** } \\
\hline Yes & 25 & $14.83 \pm 8.13$ & 15.00 & $10.50-18.00$ & $z=-4.004$ & $<0.0001$ \\
\hline No & 342 & $9.73 \pm 8.00$ & 8.00 & $4.00-13.00$ & & \\
\hline \multicolumn{7}{|l|}{ Constipation $* *$} \\
\hline Yes & 137 & $11.52 \pm 8.00$ & 10.00 & $6.00-15.00$ & $z=-3.153$ & 0.002 \\
\hline No & 240 & $9.45 \pm 8.14$ & 7.00 & $3.00-14.00$ & & \\
\hline
\end{tabular}




\begin{tabular}{|l|c|c|c|c|c|c|}
\hline \multicolumn{2}{|l|}{ History of urinary tract infection $\mathrm{b}^{* * *}$} & & & & \\
\hline Yes & 232 & $11.11 \pm 8.67$ & 9.00 & $4.00-16.00$ & z=-2.915 & 0.004 \\
\hline No & 132 & $8.30 \pm 6.51$ & 7.00 & $4.00-11.00$ & & \\
\hline SUI in the mother and/or sister b,** & & & & & \\
\hline Yes & 158 & $12.14 \pm 8.70$ & 11.00 & $5.00-17.00$ & $z=-4.789$ & $<0.0001$ \\
\hline No & 135 & $7.87 \pm 7.23$ & 7.00 & $3.00-10.50$ & & \\
\hline Body mass index* & & & & & & \\
\hline$\leq 24.9 \mathrm{~kg} / \mathrm{m}^{2}$ & 133 & $8.21 \pm 7.35$ & 6.00 & $3.00-12.00$ & $X^{2}=15.406$ & $<0.0001$ \\
\hline $25.0-29.9 \mathrm{~kg} / \mathrm{m}^{2}$ & 142 & $10.51 \pm 7.30$ & 9.00 & $5.00-13.00$ & & \\
\hline$\geq 30.0 \mathrm{~kg} / \mathrm{m}^{2}$ & 102 & $12.36 \pm 9.57$ & 10.50 & $4.00-18.00$ & & \\
\hline Diabetes** & & & & & \\
\hline Yes & 44 & $14.23 \pm 10.23$ & 14.00 & $7.50-18.00$ & $₹=-3.107$ & 0.002 \\
\hline No & 333 & $9.67 \pm 7.68$ & 8.00 & $4.00-13.00$ & & \\
\hline
\end{tabular}

BFLUTS-SF: Bristol Female Lower Urinary Tract Symptoms-Short Form; $\overline{\mathrm{X}} \pm$ SD: Mean \pm Standard Deviation ${ }^{a}$ Responses such as "both vaginal delivery and cesarean section" were excluded from the statistical analysis. ' Responses such as "I don't know" were excluded from the statistical analysis. *Kruskal Wallis test was used. **Mann-Whitney $\mathrm{U}$ test was used.

Table 3. Multiple Linear Regression Analysis for Variables Influencing the BFLUTS-SF Scores of Turkish Women

\begin{tabular}{|c|c|c|c|c|c|c|}
\hline & $B$ & SE & $\beta$ & $\mathrm{t}$ & $p$ & VIF \\
\hline Constant & 3.112 & 2.495 & & 1.247 & 0.214 & \\
\hline \multicolumn{7}{|l|}{ Age group (years) } \\
\hline $30-39$ vs. $19-29$ & -0.384 & 1.455 & -0.023 & -0.264 & 0.792 & 2.269 \\
\hline $40-49$ vs. $19-29$ & 0.029 & 1.501 & 0.002 & 0.019 & 0.985 & 2.351 \\
\hline$\geq 50$ vs. $19-29$ & -1.312 & 2.389 & -0.062 & -0.549 & 0.583 & 3.937 \\
\hline \multicolumn{7}{|l|}{ Parity } \\
\hline$\geq 1$ vs. no child bearing & 1.153 & 2.049 & 0.033 & 0.563 & 0.574 & 1.077 \\
\hline \multicolumn{7}{|l|}{ Mode of delivery } \\
\hline Cesarean section $v s$, vaginal birth & 1.041 & 1.071 & 0.062 & 0.972 & 0.332 & 1.258 \\
\hline \multicolumn{7}{|l|}{ Menopause status } \\
\hline Yes vs. no & 4.351 & 1.925 & 0.213 & 2.260 & 0.025 & 2.753 \\
\hline \multicolumn{7}{|l|}{ Chronic Cough } \\
\hline Present $v$ s. absent & 3.519 & 1.661 & 0.129 & 2.118 & 0.035 & 1.148 \\
\hline \multicolumn{7}{|l|}{ Constipation } \\
\hline Present $v s$. absent & 0.056 & 0.997 & 0.003 & 0.057 & 0.955 & 1.078 \\
\hline \multicolumn{7}{|l|}{ SUI in the mother and/or sister } \\
\hline Present $v$ s. absent & 3.265 & 1.033 & 0.201 & 3.160 & 0.002 & 1.253 \\
\hline \multicolumn{7}{|l|}{ BMI } \\
\hline $25.0-29.9 \mathrm{~kg} / \mathrm{m}^{2}$ vs. $\leq 24.9 \mathrm{~kg} / \mathrm{m}^{2}$ & 1.247 & 1.150 & 0.075 & 1.085 & 0.279 & 1.457 \\
\hline$\geq 30.0 \mathrm{~kg} / \mathrm{m}^{2} v \mathrm{~s} . \leq 24.9 \mathrm{~kg} / \mathrm{m}^{2}$ & 0.591 & 1.274 & 0.033 & 0.464 & 0.643 & 1.590 \\
\hline \multicolumn{7}{|l|}{ Diabetes } \\
\hline Present $v s$. absent & 0.108 & 1.546 & 0.004 & 0.070 & 0.945 & 1.228 \\
\hline \multicolumn{7}{|l|}{ History of a previous big baby } \\
\hline Present $v s$. absent & 4.339 & 1.591 & 0.166 & 2.728 & 0.007 & 1.137 \\
\hline \multicolumn{7}{|l|}{ SUI history in previous pregnancy } \\
\hline Present $v s$. absent & 3.975 & 1.752 & 0.209 & 2.269 & 0.024 & 2.610 \\
\hline \multicolumn{7}{|l|}{ SUI history in the postnatal period } \\
\hline Present $v s$. absent & 3.096 & 1.815 & 0.163 & 1.706 & 0.089 & 2.800 \\
\hline \multicolumn{7}{|l|}{ History of UTI } \\
\hline Present $v s$ absent & 0.205 & 1.043 & 0.012 & 0.196 & 0.845 & 1.166 \\
\hline Modal Statistics & $\begin{array}{l}\mathrm{F}=6.161 ; p<0 \\
\mathrm{R}^{2}=0.319 ; \mathrm{Adj}\end{array}$ & 268. & -Wats & & & \\
\hline
\end{tabular}

B: Unstandardized coefficient; $\beta$ : Standardized coefficient; SE: Standard error; VIF: Variance inflation factor; BFLUTS-SF: Bristol Female Lower Urinary Tract Symptoms-Short Form; BMI: Body mass index SUI: Stress urinary incontinence; UTI: Urinary tract infection; $v s:$ Versus 
The BFLUTS-SF total scores of those with a chronic cough were found to be significantly higher (by 3.519 points) than those without this problem $(p=0.035)$. The BFLUTS-SF total scores of those with a mother or sister with SUI were similarly found to be significantly higher (by 3.265 points) than those without a mother or sister with SUI $(p=0.002)$. Among the individual groups of variables, the BFLUTS-SF total scores of those who gave birth to a big baby and those with a history of SUI were found to be significantly higher, by $4.339(p=0.007)$ and 3.975 points, respectively $(p=0.024)$ (Table 3

\section{DISCUSSION}

The prevalence of at least one LUTS in women aged 18 years or more has been found to vary between $27.8 \%$ and $84.0 \%$ in studies where various measurement tools were used ${ }^{8-10,12,14}$. The prevalence of LUTS in women of this age group has been reported as $71 \%$ and $83 \%$ in two studies conducted in Turkey ${ }^{11,12}$. Our rate is much higher than the results of the studies mentioned above ${ }^{8-12,14}$. The reason could be our study being conducted on patients presenting to the internal medicine outpatient departments and the prevalence of LUTS being calculated based on BFLUTS-SF.

Storage symptoms experienced during the accumulation of urine in the bladder include symptoms such as frequency, urgency, nocturia and incontinence ${ }^{26}$. The prevalence of storage symptoms has been reported to vary between $45.2 \%$ and $71.0 \%$ in studies conducted on women aged 18 years or above $^{8-10,12,14,27}$. The prevalence of frequency, urgency, nocturia, and bladder pain were found to be $12.8-32.3 \% 0^{4,7,13,14,16,17,27}, 10.2-23.5 \% 0^{4,7,14,16,17,27}, 23.4-$ $57.8 \% 0^{4,7,14,16,17,27}$, and $31.4 \% \%^{27}$, respectively in studies where various data collection tools and populations were used. The prevalence of nocturia, urgency, and frequency was $18.6-37.2 \% 0^{11,23}, 60.3-61.5 \% 0^{11,23}$, and $35.6 \%{ }^{11}$, respectively, in the studies conducted in Turkey. For reasons similar to those related to the prevalence of LUTS, the incidence of storage symptoms in women in the current study was higher than the results of the above studies.

UI, one of the storage symptoms of LUTS, causes social and hygienic problems in women and affects their quality of life negatively ${ }^{1}$. Among the UI symptoms, the prevalence of UI, UUI, SUI, and nocturnal incontinence was found to be 20.0$37.3 \% 0^{10,12,27}, 2.6-14.9^{\%} 0^{4,10,12,14,16,17}, 7.0-20.4^{\%} 0^{12,10,14,16}$, and $0.9-1.8 \% 10,14$ in the studies conducted regarding LUTS in women. UI was found to be present in 38.7$52.2^{\circ} 0^{11,23}$, UUI in $8.2 \%$, and SUI in $21.2 \%$ in the studies conducted in Turkey ${ }^{11}$. Although the rate of UI symptoms in our study was found to be close to the results reported by Zumrutbas et al. ${ }^{11}$, it was much higher than the results of other studies. The existing chronic diseases of women and the drugs they are using could have influenced the high UI rate in this study conducted at the internal medicine outpatient departments.

Voiding symptoms such as slow stream, urinary stream splitting or spraying, intermittency, hesitancy, straining, and terminal dribble are seen in the voiding phase of the bladder ${ }^{1}$. Such voiding symptoms have been reported to be less common than storage symptoms worldwide in women in the study of Irwin et $\mathrm{al}^{9}$. The prevalence of female hesitancy, intermittent urination, and straining have been found to be $3.1-8.7 \% \%^{4,10,14,16,27}, 2.7-17.6 \% 0^{4,14,16}$ and 3.3 $6.5 \% 4,10,14,16,27$ in various studies. The rate of the presence of any female voiding symptom was $37.8 \%$, intermittent stream $17.6 \%$, hesitancy $7.3 \%$, and straining $5.5 \%$ in the study of Zumrutbas, et al ${ }^{11}$. The prevalence of voiding symptoms in our study was found to be higher than the other studies due to the characteristics of the study population and the use of different measurement tools, as with the storage and UI symptoms.

LUTS is known to affect both the sexual life and quality of life in women ${ }^{2,3}$. Urine leakage was present during sexual intercourse in $4.0 \%$ of women in the study of Sever and Oskay ${ }^{23}$. This rate was $2.5 \%$ in the study of Soler et $\mathrm{al}^{16}$. The quality of life of $42.9 \%$ of the women was affected by LUTS in the same study ${ }^{16}$. The findings obtained in our study were found to be higher than the results of Soler et al. ${ }^{16}$ and Sever and Oskay ${ }^{23}$. The reason is that at least one LUTS, whether related to storage, voiding, or UI, was seen at a very high rate in our subjects.

Thinking that symptoms are a normal result of old age and not being able to talk about them due to embarrassment are among the barriers to seeking treatment for women. In addition, the lack of information, empathy, and interest of health professionals preventing patients and their relatives from speaking freely about UI constitute an obstacle to women benefiting from health services ${ }^{2}$. In addition, treatment-seeking behavior in women can also be affected depending on the severity of LUTS 3 . A study conducted in Russia, Turkey, and 
Czechoslovakia has found $37.0 \%$ of the women to receive counseling for LUTS from physicians and $34.0 \%$ from urologists with only $12.0 \%$ treated for this condition ${ }^{12}$. Only $14 \%$ of women were reported to visit a health professional for LUTS in the study of Yoo et $\mathrm{al}^{17}$. Although the ratio women seeking treatment in our study was higher than in other studies $^{12,17}$, it was not at the desired level. Therefore, awareness of both the women and the health professionals about the diagnosis and treatment of LUTS needs to be increased.

Atrophy occurring during the menopause results in changes in the urethral mucosa, bladder dysfunction, and increased urethral closing pressure ${ }^{28}$. Women going through menopause are reported to commonly complain about LUTS such as frequency, nocturia, and incontinence ${ }^{29}$. Menopausal status in women was found to approximately double the likelihood of developing LUTS in the study of Zhang et $\mathrm{al}^{4}$. The statistical relationship between the menopausal status and total BFLUTS-SF scores was found to be significant in the study of Sever and Oskay ${ }^{23}$. A study from China reported that both the risk of developing any LUTS and the severity of the symptoms are significantly increased in women in the pre- and postmenopausal period compared to those who have normal menstruation ${ }^{13}$. Our finding in this study is consistent with the literature ${ }^{2,3}$ and the results of the study above $4,13,23$.

It is reported that the intraabdominal pressure increases during coughing and that lower urinary system dysfunction may develop due to changes in the bronchi. Coughing has been reported to weaken the pelvic floor and potentially worsen existing UI symptoms. In addition, it is reported that the drugs used for cough can also affect the urinary system ${ }^{20}$. Chronic cough was reported to have a significant effect on the total scores of BFLUTS-SF in a study conducted on adolescent pregnant women ${ }^{30}$. Our study results are similar to the literature.

The statistical difference between the presence of SUI and UI in the mother was found to be significant in study conducted on women in the climacteric period $^{28}$. The mean total score of BFLUTS-SF of those with a mother or a sister with UI was found to be significantly higher than those without a mother or sister with UI in a study conducted on adolescent pregnant women ${ }^{30}$. Our result supports the results of the above study 28,30 .

Injuries to the pelvic and pudendal nerves and damage to the pelvic floor, during vaginal labor in particular, are one of the risk factors for the development of SUI in women ${ }^{2,3}$. Besides, macrosomic birth is also reported to cause weakening of the pelvic floor ${ }^{18}$. Fetal weight was found to increase the probability of developing LUTS approximately 1.4 times in the study of Zhang et $\mathrm{al}^{4}$. The statistical relationship between giving vaginal birth at $4 \mathrm{~kg}$ or above and the total BFLUTS-SF scores was not found to be significant in the study of Sever and Oskay ${ }^{23}$. A minor relationship was found to be present between the occurrence of LUTS and fetal weight in another study ${ }^{31}$. Our findings were similar to those of Zhang et al. ${ }^{4}$ and Alling Møller et $\mathrm{al}^{31}$.

Lower and upper urinary system and pelvic floor changes develop due to the hormonal, anatomical, and physiological changes that occur in women. The strained pelvic floor and increasing pressure, increased mobility of the bladder and urethra, relaxation of connective tissue, increased glomerular filtration rate and urinary output, the bladder becoming hyperemic and edematous, and the development of physiological nephrosis and hydroureter due to the enlarging uterus during pregnancy trigger the development of SUI in females. The UI that occurs during pregnancy can become permanent ${ }^{32}$. A significant relationship is reported between the previous pregnancies of women and development of $\mathrm{UI}^{28}$. The statistical relationship between UI in previous pregnancies and the total scores of BFLUTS-SF was found to be significant in a study conducted on adolescent pregnant women ${ }^{30}$. Our result supports the results of the above study 28,30 .

The presented study had some limitations. First of all, the questions were answered the way the women remembered the issues, and the data obtained according to the verbal responses of the women will be subject to increased bias. Secondly, the study was performed in a province and the results of this sectional study cannot be generalized to women from various cultures living in various locations within the country. Multicenter studies on subjects that represent the women of all the country therefore need to be conducted.

We found in our study that LUTS was present in approximately 9 out of 10 women and the most common symptom was related to storage. These symptoms had a negative effect on the sexual life and quality of life of the women. Considering the prevalence and effects of LUTS, the fact that only 
four out of 10 women show treatment-seeking behavior requires careful consideration. Therefore, conducting new studies on the barriers that affect treatment-seeking behavior may increase women's use of health services related to LUTS. Besides, increasing the awareness of both women in the general population and healthcare professionals on this issue through training may lead to an increase in treatment-seeking behavior. Considering the risk factors affecting the development of LUTS in our study, it is necessary to inform women and health professionals about the importance of protecting and maintaining the pelvic floor in order to prevent the changes during the menopause, pregnancy, and labor and therefore to prevent the symptoms and decrease their severity, and to treat health problems such as chronic cough promptly.

Yazar Katkılari: Calısma konsepti/Tasarımı: AZD, SK; Veri toplama: AZD; Veri analizi ve yorumlama: SK, RC; Yazı taslağı: AZD, SK, RC

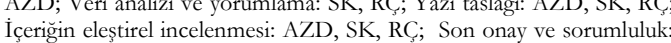
AZD, SK, RÇ; Teknik ve malzeme desteği: AZD, SK, RÇ-; Süpervizyon: AZD, SK, RÇ; Fon sağlama (mevcut ise): yok.

Etik Onay: Bu çalıșma için Niğde Ömer Halisdemir Üniversitesi Rektörlüğü Genel Sekreterlik Etik Kurulundan 25.04.2018 tarih ve 2018/08-11 saylı kararı ile etik onay alınmıştır.

Hakem Değerlendirmesi: Dış bağımsız.

Çıkar Çatışması: Yazarlar çıkar çatışması beyan etmemişlerdir.

Finansal Destek: Yazarlar finansal destek bevan etmemişlerdir.

Author Contributions: Concept/Design : AZD, SK; Data acquisition: AZD; Data analysis and interpretation: SK, RÇ; Drafting manuscript: AZD, SK, RÇ; Critical revision of manuscript: AZD, SK, RÇ; Final approval and accountability: AZD, SK, RC; Technical or material support: AZD, SK, RC; Supervision: AZD, SK, RÇ; Securing funding (if available): $\mathrm{n} / \mathrm{a}$

Ethical Approval: Ethical approval was obtained for this study from the Ethics Committee of the Presidency of Niğde Ömer Halisdemi University, with the decision dated 25.04.2018 and numbered 2018/08 11.

Peer-review: Externally peer-reviewed.

Conflict of Interest: Authors declared no conflict of interest.

Financial Disclosure: Authors declared no financial support

\section{REFERENCES}

1. Abrams P, Cardozo L, Fall M, Griffiths D, Rosier P, Ulmsten $U$ et al. The standardisation of terminology in lower urinary tract function: report from the Standardisation Sub-committee of the International Continence Society. Urology. 2003;61:37-49.

2. Bradway C, Coyne KS, Irwin D, Koop Z. Lower urinary tract symptoms in women- a common but neglected problem. J Am Acad Nurse Pract. 2008;20:311-8.

3. Bilgic D, Kizilkaya Beji N. Lower urinary tract symptoms in women and quality of life. International Journal of Urological Nursing. 2010;4:97-105.

4. Zhang W, Song Y, He X, Xu, B, Huang H, He C et al. Prevalence and risk factors of lower urinary tract symptoms in Fuzhou Chinese women. Eur Urol. 2005;48:309-13.
5. Kupelian V, Wei JT, O’Leary MP, Kuek JW, Litman HJ, Link CL et al. Prevalence of lower urinary tract symptoms and effect on quality of life in a racially and ethnically diverse random sample: the Boston Area Community Health (BACH) Survey. Arch Intern Med. 2006;166:2381-87.

6. Coyne KS, Sexton CC, Thompson CL., Milson I, Irwin D, Kopp ZS et al. The prevalence of lower urinary tract symptoms (LUTS) in the USA, the UK and Sweden: results from the epidemiology of LUTS (EpiLUTS) study. BJU Int. 2010;104:352-60.

7. Chuang F-C, Kuo H-C. Prevalence of lower urinary tract symptoms in indigenous and non-indigenous women in Eastern Taiwan. J Formos Med Assoc. 2010;109;228-36.

8. Lee Y-S, Lee K-S, Jung, JH, Han DH, Oh S-J, Seo JT et al. Prevalence of overactive bladder, urinary incontinence, and lower urinary tract symptoms: results of Korean EPIC study. World J Urol. 2011;29:185-90.

9. Irwin DE, Kopp ZS, Agatep B, Milsom L, Abrams P. Worldwide prevalence estimates of lower urinary tract symptoms, overactive bladder, urinary incontinence and bladder outlet obstruction. BJU Int. 2011;108:1132-38.

10. Wu M-P, Hsu Y-W, Weng S-F, Ho C-H., Wang J-J., Tong Y-C. Healthcare seeking prevalence of lower urinary tract symptoms among national health insurance enrollees in Taiwan, 2000-2009. Urology. 2013;81:61-5.

11. Zumrutbas AE, Bozkurt AI, Tas E, Acar CI, Alkis O, Coban $\mathrm{K}$ et al. Prevalence of lower urinary tract symptoms, overactive bladder and urinary incontinence in western Turkey: Results of a population-based survey. Int J Urol. 2014;21:1027-33.

12. Kogan MI, Zachoval R, Ozyurt C, Schäfer T, Christensen N. Epidemiology and impact of urinary incontinence, overactive bladder, and other lower urinary tract symptoms: results of the EPIC survey in Russia, Czech Republic, and Turkey. Curr Med Res Opin. 2014;30:2119-30.

13. Zhang L, Zhu L, Xu T, Lang J, Li Z, Gong J, et al. A population-based survey of the prevalence, potential risk factors, and symptom specific bother of lower urinary tract symptoms in adult Chinese women. Eur Urol. 2015;68:97-112.

14. Wang $\mathrm{Y}, \mathrm{Hu} \mathrm{H}, \mathrm{Xu} \mathrm{K}$, Wang $\mathrm{X}, \mathrm{Na} \mathrm{Y}$, Kang X. Prevalence risk factors and the bother of lower urinary tract symptoms in China: A population-based survey. Int Urogynecol J. 2015;26:911-19.

15. Chapple C, Castro-Diaz D, Chuang Y-C, Lee K-S, Liao L, Liu S-P et al. Prevalence of lower urinary tract symptoms in China, Taiwan, and South Korea: results from a cross-sectional, population-based study. Adv Ther. 2017;34:1953-65.

16. Soler R, Gomes CM, Averbeck MA, Koyama M. The prevalence of lower urinary tract symptoms (LUTS) in 
Brazil: Results from the epidemiology of LUTS (Brazil LUTS) Study. Neurourol Urodyn. 2018;37:1356-64.

17. Yoo TK., Lee K-S, Sumarsono B, Kim S-T, Kim H-J, Lee H-C et al. The prevalence of lower urinary tract symptoms in population aged 40 years or over, in South Korea. Invest Clin Urol. 2018;59:166-176.

18. Takahashi S, Takei M, Nishizawa O, Yamaguchi O, Kato K, Gotoh $\mathrm{M}$ et al. Clinical guideline for female lower urinary tract symptoms. Low Urin Tract Symptoms. 2016;8:5-29.

19. Vahabi B, Wagg AS., Rosier PFWM., Rademarkers KLJ, Denys M-A, Pontari M et al. Can we define and characterize the aging lower urinary tract?-ICI-RS 2015. Neurourol Urodyn. 2017;36:854-58.

20. Yu C-J, Hsu C-C, Lee W-C, Chiang P-H, Chuang YC. Medical diseases affecting lower urinary tract function. Urol Sci. 2013;24:41-5.

21. Cox L, Rovner ES. Lower urinary tract symptoms in women: epidemiology, diagnosis, and management. Curr Opin Urol. 2016;26:328-33.

22. Erdoğan S, Nahcivan N, Esin N. Research in Nursing: Process, Practice and Critical, İstanbul, Nobel Kitabevleri, 2015.

23. Sever N, Oskay U. An investigation of lower urinary tract symptoms in women aged 40 and over. Low Urin Tract Symptoms. 2017;9:21-26.

24. Jackson S, Donovan J, Brookes S. The Bristol Female Lower Urinary Tract Symptoms Questionnaire: development and Psyhometric testing. Br J Urol. 1996;77:805-12.

25. Güngör F. Comparison of the clinical and urodynamic effects of TVT and TVT-O in the treatment of stress urinary incontinence (PhD Thesis). Istanbul, Istanbul University, 2005.

26. Harlow BL, Bavendam TG, Palmer MH, Brubaker L, Burgio KL, Lukacz ES et al. The prevention of lower urinary tract symptoms (PLUS) research consortium: A transdisciplinary approach toward promoting bladder health and preventing lower urinary tract symptoms in women across the life course. J Womens Health. 2018;27:283-89.

27. Oriá MOB, Mitchell EM, Vasconcelos CTM, de Oliveria TDA, Lopes LG, de Menezes PR et al. Prevalence of lower urinary tract symptoms and social determinants in primary care users in Brazil. Int Urogynecol J. 2018;29:1825-32.

28. Güvenç G, Kocaöz S, Kök G. Quality of life in climacteric Turkish women with urinary incontinence. Int J Nurs Pract. 2016;22:649-59.

29. Calleja-Agius J, Brincat MP. The urogenital system and the menopause. Climacteric. 2015;18:18-22.

30. Aydin A, Kocaöz S, Kara P. Prevalence of lower urinary tract symptoms in pregnant adolescents and the influencing factors. J Pediatr Adolesc Gynecol. 2020;33:160-66.

31. Alling Møller L, Lose G, Jørgensen T. Risk factors for lower urinary tract symptoms in women 40 to 60 years of age. Obstet Gynecol. 2000;96:446-51.

32. Kocaöz S, Eroğlu K. Conservative treatment methods of stress urinary incontinence during pregnancy and after vaginal delivery and roles of nurse: review. Turkiye Klinikleri J Nurs Sci. 2009;1:94-102. 